DE SOUZA, Eliton Felipe. A disputa hegemônica brasileira com a república da argentina - o caso da ingerência na Bolívia. Revista Eletrônica Direito e Política, Programa de Pós-Graduação Stricto Sensu em Ciência Jurídica da UNIVALI, Itajaí, v.14, n.1, $1^{0}$ quadrimestre de 2019. Disponível em: www.univali.br/direitoepolitica - ISSN 1980-7791

\title{
A DISPUTA HEGEMÔNICA BRASILEIRA COM A REPÚBLICA DA ARGENTINA - O CASO DA INGERÊNCIA NA BOLÍVIA
}

\author{
THE BRAZILIAN HEGEMONIC DISPUTE WITH THE ARGENTINIAN REPUBLIC - \\ THE INTERFERENCE IN BOLIVIA CASE
}

Eliton Felipe de Souza ${ }^{1}$

\begin{abstract}
RESUMO
Este trabalho pretende lançar luz sobre as relações de dependência que subjugaram as populações latino-americanas durante a segunda metade do século $X X$, destacando que estas não existiram apenas externamente, pelo domínio do imperialismo, mas, também, internamente, em uma lógica política e social subimperialista, tendo como contexto histórico analisado, os 21 anos da ditadura militar brasileira (1964-1985). A pretensão, portanto, é a de evidenciar que entre a exploração imperialista estadunidense e os golpes militares na América Latina, existiam políticas de Estado praticadas pelos ocupantes do poder brasileiro ambicionando garantir-Ihes o papel de potência regional em uma disputa direta com a vizinha Argentina, e que essas práticas eram realizadas com a conivência e até mesmo o apoio dos Estados Unidos que tinha no Brasil o ponto de suporte para a difusão dos interesses capitalistas na América do Sul. Para a realização desse trabalho, portanto, foi necessária a profunda análise e comparação de documentos oficiais dos governos brasileiro, argentino, boliviano e estadunidense, produzidos pelas chancelarias desses países e que demonstram a atuação dos chefes militares brasileiros em relação aos países da América Latina, neste artigo especificamente, um estudo das ingerências sobre a Bolívia.
\end{abstract}

PALAVRAS-CHAVE: América Latina; Ditadura Militar; Direito Internacional; Autodeterminação dos Povos; Diplomacia.

\section{ABSTRACT}

This paper aims to shed a light on the dependency relationship that subjugated the Latin American population during the second half of XX century, highlighting that those relationships didn't exist only externally, under imperialism domain, but also internally, in a political and social sub imperialist logic, having as historical context analyzed, the 21 years of military dictatorship in Brazil (1964-1985). The goal, however, is to show that between the imperialist exploitation from the United States and the military coups in Latin America, there were state policies being done by the Brazilian authorities willing to ensure them the role as a regional power in a direct dispute with the neighbor Argentina, and that those practices were done

\footnotetext{
${ }^{1}$ Doutorando em História pela Universidade do Estado de Santa Catarina - UDESC, Florianópolis SC - Brasil. Mestre em Sociologia Política pela Universidade Federal de Santa Catarina. Professor titular na Universidade do Vale do Itajaí, E-mail: elitonfelipe@gmail.com. ORCID: https://orcid.org/00000002-4534-0987
} 
DE SOUZA, Eliton Felipe. A disputa hegemônica brasileira com a república da argentina - o caso da ingerência na Bolívia. Revista Eletrônica Direito e Política, Programa de Pós-Graduação Stricto Sensu em Ciência Jurídica da UNIVALI, Itajaí, v.14, n.1, $1^{0}$ quadrimestre de 2019. Disponível em: www.univali.br/direitoepolitica - ISSN 1980-7791

with the connivance and even the support from the United States, that had in Brazil a support to the propagation of the capitalist interests in South America. In order to carry out this work, therefore, a thorough analysis of the official documents of the Brazilian, Argentine, Bolivian and American governments produced by the chancelleries of these countries and which demonstrate the performance of the Brazilian military chief's in performance on the relationship with Latin American countries, in this particular paper, a study about the interference in Bolivia.

KEYWORDS: Latin America; Military dictatorship; International Right; Selfdetermination; Diplomacy.

\section{INTRODUÇÃO}

Em casos como o da usurpação de um território, o espaço físico acaba por ser vital na estratégia política dos Estados e a América Latina não seria uma exceção. Ainda que o atraso do continente, em algumas interpretações estivesse ligado aos "males" do passado colonial e mantido pelo conservadorismo das classes dirigentes, essa permanência se deu, em certa medida, apoiada nas relações de poder estabelecidas entre as elites locais e a exploração imperialista e as elites locais e os Estados latino-americanos no contexto interno e regional desses países.

No continente, os processos internos de formação das nações foram circunstâncias geopolíticas do sistema de estados com uma influência formativa nas estruturas políticas, econômicas e sociais destes países. Este artigo pretende então, abordar e propor uma interpretação acerca dos elementos sociais e históricos que foram mobilizados pelos governos de Brasil e Argentina para configurar as relações de dependência e dominação, atentando para estratégias nacionais de desenvolvimento capitalista e de projetos hegemônicos regionais. Para isso, levase em consideração o fato de que "a política externa, em geral, acaba expressando as concepções gestadas pela diplomacia estatal, tendo posteriormente a aprovação presidencial"2. São integrantes das elites que acabam por atuar no alto escalão dos Ministérios de Relações Exteriores.

Como veremos, a cooperação internacional na América do Sul, durante a ditadura militar brasileira, no entanto, não respeitava as ações jurídicas dos países vizinhos, estabelecendo "meios que permitem aos países desenvolverem a cooperação recíproca para o exercício de sua atividade jurisdicional"3. Pelo contrário, as ações

\footnotetext{
2 MARIANO, MP. A diplomacia e a continuidade na política externa brasileira. In: A política externa brasileira e a integração regional: uma análise a partir do Mercosul. São Paulo: Editora UNESP, 2015, p. 34.

3 MORAIS, Lindocastro Nogueira de; LIMA, Jhéssica Luara Alves de. Cooperação internacional em matéria de prova civil. Revista Eletrônica Direito e Política, Programa de Pós-Graduação Stricto Sensu em Ciência Jurídica da UNIVALI, Itajaí, v.11, n.3, $3^{\circ}$ quadrimestre de 2016. Disponível em: www.univali.br/direitoepolitica, p. 1046.
} 
DE SOUZA, Eliton Felipe. A disputa hegemônica brasileira com a república da argentina - o caso da ingerência na Bolívia. Revista Eletrônica Direito e Política, Programa de Pós-Graduação Stricto Sensu em Ciência Jurídica da UNIVALI, Itajaí, v.14, n.1, $1^{0}$ quadrimestre de 2019. Disponível em: www.univali.br/direitoepolitica - ISSN 1980-7791

políticas brasileiras demonstravam o claro interesse em estabelecer o controle hegemônico da região.

Este trabalho, portanto, está construído em torno da ideia de que a exploração e as relações assimétricas e hegemônicas contaram com estratégias nacionais desenvolvidas pelas elites em desfavor de nações mais vulneráveis, num intrincado processo entre direito internacional e interesses capitalistas locais. Sabendo que "para viabilizar a cooperação internacional, os países firmam acordos e tratados internacionais, bilaterais ou multilaterais"4 e que "a soberania de cada país deve ser respeitada [e] os Estados Partes devem cumprir suas obrigações [...] sempre respeitando os princípios da igualdade soberana e da integridade territorial [...] sem interferir nos assuntos internos dos outros Estados" ${ }^{\prime 5}$, o que verificamos é que as articulações políticas estabelecidas pela ditadura brasileira se definem pelo conceito de subimperialismo, que propõe entender o desenvolvimento a partir de uma hegemonia regional, quando a burguesia de países periféricos estende seus objetivos econômicos sobre outras nações, mas permanecem submetidas ao capital estrangeiro de países desenvolvidos, particularmente no contexto histórico aqui delimitado, quando da imposição de uma ditadura militar no Brasil, posteriormente seguida pela Argentina.

Em meio a Teoria da Dependência, Ruy Mauro Marini, apreendeu o conceito de subimperialismo "para a realidade brasileira dos anos 1960 e 1970, [expondo] os fatores que o levavam a crer que o Brasil desempenhava esse papel no plano regional"6.

Tal assertiva fica clara sob a luz de centenas de documentos que revelam o interesse por trás do jogo político internacional e evidenciam as táticas de Estado desveladas por meio da história das Relações Internacionais. O núcleo desta pesquisa está na compreensão das atividades dos governos militares brasileiros nos países vizinhos, com recorte específico para a Bolívia7, como parte de um processo de disputas regionais e de construção de hegemonia internacional durante os anos em que os generais detiveram o poder no Brasil.

\footnotetext{
4 MORAIS, Lindocastro Nogueira de; LIMA, Jhéssica Luara Alves de. Cooperação internacional em matéria de prova civil. p. 1046-1047.

5 MORAIS, Lindocastro Nogueira de; LIMA, Jhéssica Luara Alves de. Cooperação internacional em matéria de prova civil. p. 1047.

${ }^{6}$ LIMA, Rafael Teixeira de. Entre o imperialismo e o subimperialismo: a projeção brasileira à Bolívia e ao Peru nos governos Lula da Silva (2003-2010). Rebela. Florianópolis, v.6, n.3. set./dez. 2016, p. 530-545.

7 Escolhemos a Bolívia para este artigo, pois, de acordo com as pesquisas que realizamos, esta foi uma das nações mais afetadas pela ingerência brasileira e argentina.
} 
DE SOUZA, Eliton Felipe. A disputa hegemônica brasileira com a república da argentina - o caso da ingerência na Bolívia. Revista Eletrônica Direito e Política, Programa de Pós-Graduação Stricto Sensu em Ciência Jurídica da UNIVALI, Itajaí, v.14, n.1, $1^{0}$ quadrimestre de 2019. Disponível em: www.univali.br/direitoepolitica - ISSN 1980-7791

A vasta documentação investigada para dar suporte à nossa interpretação, assegura a amplitude de perspectiva que constitui a escolha metodológica para a exposição deste artigo. Foram coletadas cerca de mil páginas de documentos de cinco acervos organizados no Arquivo Nacional e no Arquivo Histórico do Itamaraty, em Brasília; no Archivo de Cancillería, em Buenos Aires; e na documentação acessível remotamente do Departamento de Estado dos Estados Unidos. Para definir esta imensa produção de documentos, Fico propõe o termo "ditadura documentada". Para o autor, "se o desafio anterior eram as fontes, passou a ser, então, a análise, o estabelecimento de novas interpretações e de hipóteses explicativas" ${ }^{\prime 2}$. Dessa forma, nosso olhar volta-se, aqui, para a disputa hegemônica entre Brasil e Argentina.

A ditadura militar brasileira provocou mudanças importantes interna e externamente. Em fins de 1970, por exemplo, o presidente Garrastazu Médici ofereceu aos adversários políticos do governo boliviano, dinheiro, aviões, mercenários, áreas de treinamento em território brasileiro, suporte logístico com aviões militares, armamentos e munições, além do suporte das tropas do II Exército, para ajudar no golpe de Estado.

O avanço da política exterior dos Estados Unidos durante a primeira metade do século XX e as ações de países periféricos, como o Brasil, a partir da década de 1950, aparecem como situações preponderantes para a compreensão do conceito de subimperialismo. Esta política impõe "uma relação de subordinação entre nações formalmente independentes, em cujo marco as relações de produção das nações subordinadas são modificadas ou recriadas para assegurar a reprodução ampliada da dependência" ${ }^{\prime \prime}$. A ação dos militares, portanto, não parece ter ocorrido apenas para defender os interesses internos brasileiros ou assegurar o domínio dos Estados Unidos na região, mas para defender a supremacia da elite brasileira frente à Argentina. Como veremos no decorrer deste artigo, mesmo subordinado às políticas de Estado estadunidenses, os governos ditatoriais brasileiros gozavam de certa liberdade para impor a sua vontade sobre os países vizinhos.

\section{BRASIL E ARGENTINA - UMA DISPUTA HEGEMÔNICA}

Com o fim da Segunda Guerra Mundial, o desenvolvimento do modo de produção capitalista e do imperialismo conheceu uma nova fase, marcada pela internacionalização da acumulação capitalista, dando lugar a "subcentros econômicos, dotados de autonomia relativa, embora subordinados ao imperialismo

\footnotetext{
${ }^{8}$ FICO, Carlos. Ditadura militar brasileira: aproximações teóricas e historiográficas. Revista Tempo e Argumento, Florianópolis, v. 9, n. 20, p. 05 - 74. jan./abr. 2017.

9 MARINI, Ruy Mauro. Dialéctica de la dependencia. 2. ed. México: Era, 1974, p. 134-135.
} 
DE SOUZA, Eliton Felipe. A disputa hegemônica brasileira com a república da argentina - o caso da ingerência na Bolívia. Revista Eletrônica Direito e Política, Programa de Pós-Graduação Stricto Sensu em Ciência Jurídica da UNIVALI, Itajaí, v.14, n.1, $1^{0}$ quadrimestre de 2019. Disponível em: www.univali.br/direitoepolitica - ISSN 1980-7791

dominante ${ }^{10}$. Além disso, a escolha adotada, no que se refere à política externa desses subcentros, tem importância no relacionamento com os países centrais e na posição que os periféricos assumiram regionalmente.

Para Marini "el régimen militar [...] inauguró un nuevo estilo en la política exterior de Brasil, cuyo principal objetivo parece ser [...] una perfecta adecuación entre los intereses nacionales del país y la política de hegemonía mundial llevada a cabo por Estados Unidos"11. O governo ditatorial brasileiro passou a trabalhar para garantir os interesses dos Estados Unidos, como um centro de irradiação do modo de produção capitalista, ainda que com certa independência, ampliando o próprio grau de importância na América do Sul.

As medidas adotadas pelo governo militar, passaram a favorecer a concentração de capital nas mãos dos grupos mais poderosos, beneficiando os conglomerados estrangeiros e a grande burguesia nacional. "Esa política obedece también a las exigencias planteadas por el propio desarrollo capitalista brasileño, como son la rebaja de los salarios y la racionalización de la producción"12. Para Marini, é nesse momento que a burguesia brasileira passa a aceitar o papel de sócio menor na aliança com os capitais estrangeiros, intensificando a capitalização, rebaixando ainda mais o nível de vida popular e concentrando o capital, antes disperso na pequena e média burguesia.

Nesse ponto o Brasil se destaca frente à Argentina, pois, seja pela política de alianças com o latifúndio exportador, seja pela integração ao imperialismo, a produção crescente da burguesia brasileira, resultante da modernização tecnológica e do suporte financeiro dado pelos governos militares, expandiu o mercado brasileiro para a exportação de produtos industrializados. Enquanto isso, como demonstra Luce:

A Argentina, apesar de ter atingido a etapa monopólica e financeira e de ter liderado, antes da ascensão do Brasil, a produção industrial na América do Sul, detém particularidades históricas que a impediram de se tornar uma formação subimperialista. Como observado, as divisões no seio da

\footnotetext{
10 LUCE, Mathias Seibel. A teoria do subimperialismo em Ruy Mauro Marini: contradições do capitalismo dependente e a questão do padrão de reprodução do capital. A história de uma categoria. 2011. 225. Tese (Doutorado em História) Programa de Pós-Graduação em História da Universidade Federal do Rio Grande do Sul (PPGH-UFRGS), Porto Alegre, 2011, p. 74.

11 MARINI, Ruy Mauro. La dialéctica del desarrollo capitalista en Brasil (1966). In: MARTINS, Carlos Eduardo. América Latina, dependencia y globalización/Ruy Mauro Marini: antología y presentación. México, D. F.: Siglo XXI; Buenos Aires: CLACSO, 2015, p. 58.

12 MARINI, Ruy Mauro. La dialéctica del desarrollo capitalista en Brasil (1966), p. 58.
} 
DE SOUZA, Eliton Felipe. A disputa hegemônica brasileira com a república da argentina - o caso da ingerência na Bolívia. Revista Eletrônica Direito e Política, Programa de Pós-Graduação Stricto Sensu em Ciência Jurídica da UNIVALI, Itajaí, v.14, n.1, $1^{0}$ quadrimestre de 2019. Disponível em: www.univali.br/direitoepolitica - ISSN 1980-7791

burguesia argentina impediram [...] um projeto nacional com força suficiente para uma expansão além-fronteiras ${ }^{13}$.

De acordo com Marini ${ }^{14}$, a diversificação econômica opõe os interesses do mercado interno aos do mercado externo, gerando o conflito entre aqueles que os constituem, situação que se agrava quando as relações sociais resultantes da industrialização não se sincronizam ao ritmo da penetração imperialista.

Esse conflito caminha de forma a tornar-se insustentável ao ponto de uma ruptura, na qual ou o país periférico opta por um desenvolvimento independente ou se submete aos interesses do capital estrangeiro. No caso do Brasil, essa mudança fazia-se latente no decorrer dos governos dos presidentes Jânio Quadros e João Goulart, caminho interrompido pelo golpe de 1964, o que explica porque a primeira fase do "gobierno militar fue la represión policíaca del movimiento de masas: la intervención en los sindicatos, la disolución de los órganos directivos populares (incluso el CGT), la persecución de los líderes obreros y campesinos, la supresión de mandatos y derechos políticos, la prisión y la tortura"15.

Com a retomada de uma política interna e externa de aproximação aos Estados Unidos, o governo militar brasileiro passou a acelerar a integração entre as economias dos dois países, se posicionando como centro difusor do imperialismo na América Latina, contudo: "no se trata de aceptar pasivamente las decisiones norteamericanas (aunque la correlación real de fuerzas lleve muchas veces a ese resultado), sino de colaborar activamente con la expansión imperialista, asumiendo en ella la posición de país clave"16.

Tal situação era identificada pela Argentina e, em 1971, o presidente Lanusse, em discurso no encerramento da IV Reunião de Chanceleres dos países da Bacia do Prata, se mostrou contrário ao modelo de política externa adotada por Brasília:

Fingindo acreditar nos comentários tendenciosos ou imprudentes de certa imprensa, o Palácio San Martin parece desejar arvorar-se em propugnador de uma cruzada contra a tese das "Fronteiras Ideológicas"[ilegível] "imperialismo" e a "liderança" brasileiros, pensamentos que, latentes nos últimos encontros mantidos entre autoridades argentinas com representantes do Uruguai, Chile e Bolívia, manifestou-se com mais desenvoltura durante o discurso pronunciado pelo

\footnotetext{
13 LUCE, Mathias Seibel. O subimperialismo, etapa superior do capitalismo dependente. Tensões mundiais. Fortaleza, v. 10, n. 18, 19, jun. 2014, p. 53.

14 MARINI, Ruy Mauro. La dialéctica del desarrollo capitalista en Brasil (1966), p. 62-63.

15 MARINI, Ruy Mauro. La dialéctica del desarrollo capitalista en Brasil (1966), p. 56.

16 MARINI, Ruy Mauro. La dialéctica del desarrollo capitalista en Brasil (1966), p. 75.
} 
DE SOUZA, Eliton Felipe. A disputa hegemônica brasileira com a república da argentina - o caso da ingerência na Bolívia. Revista Eletrônica Direito e Política, Programa de Pós-Graduação Stricto Sensu em Ciência Jurídica da UNIVALI, Itajaí, v.14, n.1, $1^{0}$ quadrimestre de 2019. Disponível em: www.univali.br/direitoepolitica - ISSN 1980-7791

presidente Lanusse, em Salta, durante a visita do presidente Allende ${ }^{17}$.

No documento parecia claro para Lanusse qual o papel desempenhado pelo governo brasileiro na América do Sul:

A orientação da chancelaria argentina parece tão evidente que "Buenos Aires Herald", ao comentar a visita do presidente chileno, em editorial sugestivamente intitulado "El Realpolitik de Lanusse", como informei vossa excelência no expediente acima referido, pondera que "A iniciativa deve ser resultante de uma genuína convicção no valor de políticas exteriores francas e abertas e não simplesmente causada pelo desejo de apresentar uma alternativa a chamada ofensiva diplomática do Brasil para lograr a liderança latino-americana".

Para Marini, o subimperialismo possui dois componentes fundamentais: "una composición orgánica media en la escala mundial de los aparatos productivos nacionales; y el ejercicio de una política expansionista relativamente autónoma", todavia, quando estas ações são aplicadas aos sub-centros, "independientemente de los esfuerzos de Argentina y otros países por acceder a un rango subimperialista, sólo Brasil expresa plenamente, en Latinoamérica, un fenómeno de esta naturaleza"18.

O golpe militar no Brasil deu início a uma nova fase de integração imperialista, exercido sob o marco da cooperação antagônica. Para Marini ${ }^{19}$, esse processo seria mais acentuado, sobretudo "allí donde se enfrentan burguesías nacionales poderosas, como es el caso de Argentina y Brasil".

A pentagonização latinoamericana e a consequente aproximação brasileira ao imperialismo dos aliados do Norte se dava por meio da ampliação de uma rede de relações subordinadas, com intercâmbio de informação, fornecimento de equipamentos militares e munição, e treinamento para segurança interna e acesso às escolas militares dos Estados Unidos, além de linhas de financiamento específicas.

${ }^{17}$ EMBAIXADA DO BRASIL NA ARGENTINA. [Telegrama] 26 jun. 1971, Buenos Aires [para] Secretaria de Estado das Relações Esteriores. Brasília. 5f. Argentina, política em relação ao Brasil. In: Coordenação-geral De Documentação Diplomática (CDO) do Ministério Das Relações Exteriores. Acervo referente às embaixadas brasileiras. Brasília: Arquivo do Itamaraty, 2017. p 01.

18 MARINI, Ruy Mauro. La acumulación capitalista mundial y el subimperialismo. In: Cuadernos Políticos n 12. México: Ediciones Era, 1977, p. 38.

19 MARINI, Ruy Mauro. La dialéctica del desarrollo capitalista en Brasil (1966), p. 77-78. 
DE SOUZA, Eliton Felipe. A disputa hegemônica brasileira com a república da argentina - o caso da ingerência na Bolívia. Revista Eletrônica Direito e Política, Programa de Pós-Graduação Stricto Sensu em Ciência Jurídica da UNIVALI, Itajaí, v.14, n.1, $1^{0}$ quadrimestre de 2019. Disponível em: www.univali.br/direitoepolitica - ISSN 1980-7791

Já em 1946, antes mesmo das ditaduras começarem a se instalar pelos países latinos, o governo estadunidense tentara se impor sobre a política argentina, mas "apesar das pressões dos EUA, Perón foi eleito com uma votação contundente, obtendo $56 \%$ dos votos" 20 . Além disso, na tentativa de manter o controle político sobre a América Latina, Washington não podia permitir a crescente organização popular no continente, o que desencadeou a série de golpes de Estado.

A Lei de Segurança Nacional, adotada em países como o Brasil, visava impedir qualquer tentativa de dissenso, situação evidenciada pelas atas das reuniões do Conselho de Segurança Nacional:

A associação das manifestações de massa com os recentes atos de terrorismos e sabotagem, repetidos em escala e vulto cada vez maiores, particularmente no RIO e em S. PAULO, caracterizam atentados flagrantes e violentos à ordem pública e ao regime. Tal estado de coisas vem produzindo gradativa sensação de insegurança à população, e, está gerando um sentimento de apreensão no seio das Fôrças [Sic] Armadas, que vêm, claramente, em tudo isso, o início da contrarevolução. Não parece haver mais dúvidas que as RECOMENDAÇÕES DE HAVANA (OLAS e outros Congressos), ultrapassado o período preparatório, encontram-se em fase de plena concretização (não só no BRASIL como na AMÉRICA LATINA), colocando na vanguarda, com vistas à tomada do poder, a classe estudantil, não só universitária como também secundarista. Engrossam e respaldam essa vanguarda estudantil, os extremistas de esquerda de todos os matizes ${ }^{21}$.

Com um processo de colonização semelhante no que se refere a exploração das riquezas por países estrangeiros (no caso Espanha para Argentina e Portugal para Brasil), os dois grandes países da América do Sul tiveram um processo de organização do espaço muito distinto. Pelo fato de ter estado sob o modelo de domínio unitário português e por ter sido a capital do império de Portugal entre 1808 e 1821, após a independência, em 1822, o Brasil "possuía viabilidade econômica, relações comerciais independentes, quadros para a administração

\footnotetext{
20 NETO, Sydenham Lourenço. A Conferência do Rio de Janeiro e o Tratado Interamericano de Assistência Recíproca: Conflitos na construção do sistema interamericano. Revista Internacional de História Política e Cultura Jurídica. Rio de Janeiro, vol. 7, n. 3, set/dez, 2015, p. 473-489. Disponível em: <http://www.historia.uff.br/revistapassagens/artigos/v7n3a32015.pdf> Acesso em: 01/01/2018, p. 477.

21 PRESIDÊNCIA DA REPÚBLICA - CONSELHO DE SEGURANÇA NACIONAL - SECRETARIA-GERAL. [Ata] 10 de julho de 1968. 79f. Ata da quadragésima primeira sessão do Conselho de Segurança Nacional. In: Documentos Revelados. Acervo referente às Atas do Conselho de Segurança Nacional 1968. Foz do Iguaçú: Arquivo Documentos Revelados, 2018, p. 05.
} 
DE SOUZA, Eliton Felipe. A disputa hegemônica brasileira com a república da argentina - o caso da ingerência na Bolívia. Revista Eletrônica Direito e Política, Programa de Pós-Graduação Stricto Sensu em Ciência Jurídica da UNIVALI, Itajaí, v.14, n.1, 10 quadrimestre de 2019. Disponível em: www.univali.br/direitoepolitica - ISSN 1980-7791

pública, legitimidade monárquica e, em vez de milícias, um verdadeiro exército que, sendo uma força luso-brasileira, em grande parte se tornou apenas brasileira"22.

Por outro lado, apesar de ter sido a primeira nação autodeterminada da América do Sul, o caso da Argentina foi o mais complexo. A independência veio após "uma longa guerra civil entre os partidários de um Estado unitário e os 'caudilhos' provinciais que, com exércitos próprios, manejavam os seus redutos"23. O país, que já nasceu como o segundo maior Estado territorial da América do Sul, teve suas fronteiras delimitadas pela geopolítica do continente, desenvolvendo rivalidades regionais com os países vizinhos. A partir daquele momento as relações entre as duas grandes nações e aspirantes a maiores potências regionais passaram a ocorrer sobre o fio de uma navalha, sempre pronta a ferir aquele que desse o primeiro passo em falso.

Em alguns momentos, a disputa entre os dois países chegava a confundir os próprios envolvidos. Em 29 de fevereiro de 1972, por exemplo, a embaixada brasileira no Chile, retransmitiu um telegrama vindo da representação do Brasil em Moscou um dia antes, no qual o embaixador brasileiro relatava informações sobre a hostilidade do representante argentino em Santiago. Segundo o documento, o embaixador portenho no Chile era "francamente contrário a à aproximação Argentino-Brasileira, procurando [...] influenciar a chancelaria de Buenos Aires"24.

No entanto, após retransmitir o telegrama de Moscou, a representação brasileira em Santiago fez questão de escrever ao governo brasileiro contrariando o colega no outro lado do planeta: "causou-me espécie a informação transmitida pelo despacho-telegráfico 87. Não acredito que seja verdadeira [...]. Tenho do embaixador argentino aqui [...] excelente impressão e só temos tido eu e meus colaboradores, provas de amizade pelo Brasil"25. O embaixador brasileiro continua afirmando sua crença na inocência do colega argentino, declarando que a imprensa chilena era formada por "partidos marxistas e imprensa de esquerda, muitos

\footnotetext{
22 NOGUEIRA, José Manuel Freire. América do Sul: uma visão geopolítica. Lisboa: Instituto da Defesa Nacional; EUROPRESS, 2015, p. 35.

23 NOGUEIRA, José Manuel Freire. América do Sul: uma visão geopolítica. p. 32.

24 Embaixada do Brasil em Santiago. [telegrama] 29 fev. 1972, Santiago [para] Secretaria de Estado das Relações Exteriores. Brasília. 1f. Santiago, política de hostilidade ao Brasil. in: Coordenaçãogeral de documentação diplomática (CDO) do Ministério das Relações Exteriores. Acervo referente às embaixadas brasileiras. Brasília: Arquivo do Itamaraty, 2017. 1p.

25 Embaixada do Brasil em Santiago. [telegrama] 29 fev. 1972, Santiago [para] Secretaria de Estado das Relações Exteriores. Brasília. 1f. Em resposta ao telegrama: Santiago, política de hostilidade ao Brasil. in: Coordenação-geral de documentação diplomática (CDO) do Ministério das Relações Exteriores. Acervo referente às embaixadas brasileiras. Brasília: Arquivo do Itamaraty, $2017 \mathrm{~b}$. p.01.
} 
DE SOUZA, Eliton Felipe. A disputa hegemônica brasileira com a república da argentina - o caso da ingerência na Bolívia. Revista Eletrônica Direito e Política, Programa de Pós-Graduação Stricto Sensu em Ciência Jurídica da UNIVALI, Itajaí, v.14, n.1, $1^{0}$ quadrimestre de 2019. Disponível em: www.univali.br/direitoepolitica - ISSN 1980-7791

auxiliados pelos brasileiros" (idem) e o embaixador de Buenos Aires, pelo contrário, não teria contato com os opositores da ditadura brasileira.

Os países da América do Sul estiveram no bojo das disputas entre Argentina e Brasil durante o século XX, os dois grandes da América do Sul revezaram-se em apoiar governantes e em estabelecer acordos bilaterais que beneficiassem um e prejudicasse o outro. Um dos países mais afetados pela disputa Brasil-Argentina foi a Bolívia. A nação andina foi uma das que se viu submetida às intenções dos vizinhos mais poderosos.

\section{A BOLÍVIA}

Na Bolívia o primeiro golpe ocorreu após as mudanças instituídas pela Revolução de 1952, liderada pelo Movimento Nacionalista Revolucionário - MNR, de Victor Paz Estenssoro, que determinara a nacionalização das minas e o monopólio da exportação de estanho, elaborara um programa de reforma agrária e instituíra o sufrágio universal. Ocorreram golpes em 1964, 1971, 1980, 1981 e mais três governos militares até outubro de 1982.

Em 1964, o General René Barrientos colocou fim ao governo do MNR dando início aos seguidos golpes de Estado. Foi sob o seu governo que o guerrilheiro Ernesto Che Guevara foi assassinado. A caça a Guevara, inclusive, contou com o auxílio da ditadura brasileira que forneceu "certa quantidade de armamento, munição e medicamentos"26, aos militares bolivianos. O General atacou as conquistas nacionalistas e reduziu os direitos trabalhistas, além de reprimir com violência toda e qualquer oposição.

Em 07 de outubro de 1970 chegou ao poder o General Juan José Torres Gonzáles que tinha como base trabalhadores e movimentos populares. Naquele momento já havia, por parte da ditadura brasileira, o receio em relação aos possíveis rumos do governo boliviano: "considerando a situação da Bolívia como país limítrofe, interessa de perto à nossa própria segurança, que não venha esse país cair na órbita dos países socialistas", ademais, o governo brasileiro entendia que era importante " uma colaboração mais acentuada entre as FFAA com suas congêneres bolivianas, ainda sob a chefia de oficiais conservadores, concorreria para 0 fortalecimento desses elementos que afinal são o baluarte da luta contra a facção esquerdista".

26 SECRETARIA DE ESTADO DAS RELAÇÕES EXTERIORES. [Estudo Especial] 14 ago. 1970, Brasília. 9f. Diretrizes de ordem política com relação a um possível agravamento da situação político-militar da Bolívia. In: Arquivo Nacional - Ministério da Justiça e Segurança Pública. Acervo da Ditadura Militar. Brasília: Arquivo Nacional, 2017, p. 09. 
DE SOUZA, Eliton Felipe. A disputa hegemônica brasileira com a república da argentina - o caso da ingerência na Bolívia. Revista Eletrônica Direito e Política, Programa de Pós-Graduação Stricto Sensu em Ciência Jurídica da UNIVALI, Itajaí, v.14, n.1, $1^{0}$ quadrimestre de 2019. Disponível em: www.univali.br/direitoepolitica - ISSN 1980-7791

No entanto, o avanço das políticas sociais desencadeou a formação da Assembleia Popular em $1^{\circ}$ de maio de 1971, com 221 delegados entre camponeses, operários, setores da classe média e partidos políticos. A reação boliviana, então, passou a conspirar contra o governo e no centro dessa conspiração encontravam-se os militares brasileiros. Um ofício do Estado Maior do Exército e da Aeronáutica, de 03 de agosto de 1970, revela que "altos Chefes militares [bolivianos] já se convenceram da impossibilidade de levarem o Presidente [Alfredo] Ovando [Candia] a descartar-se de seus compromissos com os comunistas e que por isso estão estudando a sua substituição"27.

O documento é concluído afirmando que a aliança entre as FFAA dos dois países representaria "um fortalecimento das Forças Armadas deste país para sua dupla missão de combater o movimento guerrilheiro e eliminar a influência do comunismo". O peso da informação suscitou a produção de um estudo emitido em 14 de agosto de 1970 e outro em 04 de setembro do mesmo ano, sobre a situação política boliviana, e um terceiro, de 13 de outubro de 1970, no qual o Chefe do Estado Maior das Forças Armadas, Almirante de Esquadra Murilo Vasco do Valle Silva, solicita aos Ministros da marinha, exército e aeronáutica uma resposta rápida sobre de que maneira cada ministério poderia contribuir nas questões envolvendo a Bolívia ${ }^{28}$.

Esse documento propunha a criação dos cargos de Adido Naval e Aeronáutico, na embaixada brasileira em La Paz; doação de material para o combate às guerrilhas, assim como comprovação tecnológica na produção bélica para comercialização de armas com o país vizinho; trocas técnico-profissionais entre estabelecimentos e unidades militares; integração do sistema médico-hospitalar militar boliviano ao brasileiro; e intercâmbio de representações militares em datas comemorativas das FFAA entre os dois países. A ditadura brasileira não pretendia deixar um governo de esquerda se formar no país vizinho.

Em um acordo que incluía golpistas bolivianos, Estados Unidos, Argentina e Brasil, a ditadura brasileira se mostrava a principal interessada na derrubada do governo da Bolívia: "Ningún país Ilego a tanto como Brasil. Em mayo de 1971, el general

27 EMBAIXADA DO BRASIL NA BOLÍVIA - SECRETARIA DE ESTADO DAS RELAÇÕES EXTERIORES. [Telegrama] 03 ago. 1970, Brasília [para] II Seção do Estado Maior do Exército e II Seção do Estado Maior da Aeronáutica. Brasília. 2f. Situação político-militar na Bolívia. In: Arquivo Nacional Ministério da Justiça e Segurança Pública. Acervo da Ditadura Militar. Brasília: Arquivo Nacional, 2017, p. 02.

${ }^{28}$ ESTADO MAIOR DAS FORÇAS ARMADAS. [Ofício] 03 out. 1970, Brasília [para] Secretário Geral de Segurança Nacional. Brasília. 3f. Aviso No 35 PA-2 267. In: Arquivo Nacional - Ministério da Justiça e Segurança Pública. Acervo da Ditadura Militar. Brasília: Arquivo Nacional, 2017, p. 03. 
DE SOUZA, Eliton Felipe. A disputa hegemônica brasileira com a república da argentina - o caso da ingerência na Bolívia. Revista Eletrônica Direito e Política, Programa de Pós-Graduação Stricto Sensu em Ciência Jurídica da UNIVALI, Itajaí, v.14, n.1, $1^{0}$ quadrimestre de 2019. Disponível em: www.univali.br/direitoepolitica - ISSN 1980-7791

brasileño Hugo Bethlem propuso que las naciones más importantes de sudamérica intervinieran sobre Bolívia"29.

Como retribuição às medidas adotadas por Brasília, ao assumir o poder, a ditadura Banzer converteu o Brasil em seu principal aliado econômico. A exploração dos recursos naturais, principalmente gás natural e minério de ferro, que antes eram de preferência da Argentina, passaram a ser de prioridade brasileira. "Santa Cruz fue la gran beneficiada: las armas volvieron em forma de recursos naturales" ${ }^{\prime 30}$.

Mesmo após o golpe no país vizinho, a ditadura brasileira agia para garantir que não haveria retorno de opositores ao governo boliviano. Sobre os campos de treinamento da guerrilha da Bolívia em solo chileno, a ditadura brasileira foi capaz de identificar a logística dos grupos armados, sabendo onde podia-se desembarcar as armas usadas nos treinamentos e onde se localizavam o centros de operações da guerrilha ${ }^{31}$.

De acordo com o documento, havia indícios de que a região de Santa Cruz de la Sierra oferecia "condições favoráveis a ação de guerrilha e eventualmente ao estabelecimento de uma 'zona liberada'"'32, que deveria ser logo reconhecida pelo governo de Allende.

Brasília estava de olho, também, nos apoiadores dos guerrilheiros bolivianos, como a Deputada do Partido Socialista Chileno, Carmen Lazo, "elemento de confiança de Allende [e encarregada da] ligação entre o governo chileno e os subversivos brasileiros"; a embaixada cubana em Santiago, "responsável pela coordenação superior e pela ligação com Havana"; "Fernando Roca, ex-secretário da embaixada da Bolívia em Buenos Aires", o elo entre Torres e os tupamaros; além de um representante das Forças Armadas Peronistas, que os militares brasileiros ainda não haviam identificado, mas que estaria responsável pela troca de informações entre Torres e Perón ${ }^{33}$.

29 SIVAK, Martín. El dictador elegido: biografía no autorizada de Hugo Banzer. La Paz: Plural Editores, 2001, p. 63.

30 SIVAK, Martín. El dictador elegido: biografía no autorizada de Hugo Banzer. p. 64.

31 PRESIDÊNCIA DA REPÚBLICA - SERVIÇO NACIONAL DE INFORMAÇÃO - AGÊNCIA CENTRAL. [Telegrama] 03 ago. 1970, Brasília [para] [?]. Brasília. 11f. O movimento subversivo na América Latina - Bolívia: alvo prioritário. In: Arquivo Nacional - Ministério da Justiça e Segurança Pública. Acervo da Ditadura Militar. Brasília: Arquivo Nacional, 2017, p. 01-06.

32 PRESIDÊNCIA DA REPÚBLICA - SERVIÇO NACIONAL DE INFORMAÇÃO - AGÊNCIA CENTRAL. [Telegrama] 03 ago. 1970, Brasília [para] [?]. Brasília. 11f. O movimento subversivo na América Latina - Bolívia: alvo prioritário. p. 02.

33 PRESIDÊNCIA DA REPÚBLICA - SERVIÇO NACIONAL DE INFORMAÇÃO - AGÊNCIA CENTRAL. [Telegrama] 03 ago. 1970, Brasília [para] [?]. Brasília. 11f. O movimento subversivo na América Latina - Bolívia: alvo prioritário. In: Arquivo Nacional - Ministério da Justiça e Segurança Pública.

Acervo da Ditadura Militar. Brasília: Arquivo Nacional, 2017, p. 03. 
DE SOUZA, Eliton Felipe. A disputa hegemônica brasileira com a república da argentina - o caso da ingerência na Bolívia. Revista Eletrônica Direito e Política, Programa de Pós-Graduação Stricto Sensu em Ciência Jurídica da UNIVALI, Itajaí, v.14, n.1, $1^{0}$ quadrimestre de 2019. Disponível em: www.univali.br/direitoepolitica - ISSN 1980-7791

O documento traz ainda um relatório das ações do ex-presidente Torres, exilado no Chile, como a conversa com Allende em 31 de outubro de 1971, quando o presidente chileno teria oferecido "seu país para servir de base de treinamento e de operações de guerrilhas contra a Bolívia, além de facilidades para todos os seus seguidores [...] e do auxílio que se fizesse necessário para viagens ao exterior". Torres teria viajado para a europa em novembro de 1971, encontrando-se com os dirigentes do Partido Comunista Francês que teriam the oferecido dinheiro e armas, além de participar de uma reunião em Madri com o também ex-presidente, Ovando Cândia e com o chefe de Estado argentino Juan Domingo Perón. Ao mandatário argentino, Torres teria solicitado anuência à criação de uma Frente Militar Anti-imperialista, que aglutinaria militantes de Brasil, Chile, Argentina, Uruguai e Bolívia.

Além disso, o Itamaraty agiu em conjunto com outros ministérios renegociando acordos entre Brasília e La Paz. Em 16 de março de 1973, os ministros Mário Gibson Barbosa, das Relações Exteriores; Antônio Dias Leite Júnior, de Minas e Energia; e Marcus Vinícius Pratini de Moraes da Indústria e Comércio; emitiram um estudo que expunha os desejos brasileiros em relação ao aproveitamento do gás natural boliviano ${ }^{34}$.

Um dos antecedentes para a criação deste estudo teria sido "o problema do aproveitamento por parte do Brasil das reservas bolivianas de hidrocarbonetos, apesar da presença de fatores positivos e interesses convergentes, não tem conseguido chegar a bom termo".

Como conclusão, os ministros classificavam a exploração dos hidrocarbonetos bolivianos como sendo "assunto da mais alta relevância para a segurança nacional". Além disso, procuravam apoiar as ações conjuntas entre a Petrobras e a Yacimientos Petrolíferos Fiscales Bolivianos (YPFB) ${ }^{35}$ (ibidem, p. 02).

Algumas das ações dois grandes do continente tiveram início mesmo antes da ditadura militar tomar o poder no Brasil. Até janeiro de 1956, quando foi inaugurada a estrada de ferro Santa Cruz de la Sierra-Corumbá, os bolivianos dependiam inteiramente do porto de Buenos Aires para escoar as exportações do país. Com a construção da ferrovia, a Bolívia aproximou-se do governo brasileiro, passando a ter novas opções e acirrando a disputa Argentina/Brasil.

\footnotetext{
34 MINISTÉRIOS DAS RELAÇÕES EXTERIORES; MINISTÉRIO DE MINAS E ENERGIA; MINISTÉRIO DA INDÚSTRIA E COMÉRCIO. [Ofício] 16 mar. 1973, Brasília [para] Presidência da República. 2f. Estudo Sucinto No 015/1a.SC/73. In: Arquivo Nacional. Acervo referente à ditadura militar brasileira. Brasília: Arquivo Nacional, 2017a, p. 01.

35 MINISTÉRIOS DAS RELAÇÕES EXTERIORES; MINISTÉRIO DE MINAS E ENERGIA; MINISTÉRIO DA INDÚSTRIA E COMÉRCIO. [Ofício] 16 mar. 1973, Brasília [para] Presidência da República. 2f. Estudo Sucinto No 015/1a.SC/73. p. 02.
} 
DE SOUZA, Eliton Felipe. A disputa hegemônica brasileira com a república da argentina - o caso da ingerência na Bolívia. Revista Eletrônica Direito e Política, Programa de Pós-Graduação Stricto Sensu em Ciência Jurídica da UNIVALI, Itajaí, v.14, n.1, $1^{0}$ quadrimestre de 2019. Disponível em: www.univali.br/direitoepolitica - ISSN 1980-7791

A ditadura brasileira tentou implementar uma política comercial sobre os hidrocarbonetos bolivianos. Documento de 12 de fevereiro de 1973, propunha a construção de um "complexo industrial fronteiriço, com unidades localizadas no território brasileiro e boliviano". Era imprescindível ao Brasil o proveito do gás natural boliviano e os ministros tinham em consideração o "acentuado aumento do petróleo e do gás natural" o que levaria a ditadura a conduzir "uma paulatina revisão da hipótese inicial de trabalho, envolvendo maiores quantidades, do que aquelas inicialmente previstas" ${ }^{\prime 36}$.

Alvo de constante do governo brasileiro, a Bolívia tornou-se um parceiro fundamental no jogo político subimperialista. Um documento de 1972, com 66 páginas tratando desde as questões relativas à organização político-administrativa bolivianas, até o intercâmbio cultural com o Brasil, traz a ferrovia Santa Cruz de la Sierra-Corumbá como potencial elo entre a produção brasileira e o Oceano Pacífico. A Ditadura se mostrava bastante preocupada com o estado em que a estrada de ferro se encontrava:

A par da falta de recursos do governo boliviano para mantêla em bom funcionamento, essa ferrovia ressente-se do fato de servir zonas de reduzida população e escasso poder aquisitivo. A vocação desta ferrovia, que poderá torná-la rentável em breve prazo, é a de servir a um comércio de trânsito entre a Bolívia e o exterior e entre zonas de considerável potencial de complementação, como o parque industrial de São Paulo e a região andina da Bolívia. Para isso, porém, é necessário construir o prolongamento até Cochabamba ${ }^{37}$.

Havia por parte do governo boliviano o interesse em ampliar e melhorar a estrada de ferro, mas isso deveria acontecer por meio de financiamento brasileiro para a aquisição de material rodante e de tração, para o reequipamento da ferrovia. $A$ representação brasileira na Bolívia complementava o texto com a afirmação de que, "embora interessante, essa perspectiva deverá ser analisada à luz do já elevado grau de endividamento do governo boliviano para com o Brasil".

\footnotetext{
36 MINISTÉRIOS DAS RELAÇÕES EXTERIORES; MINISTÉRIO DE MINAS E ENERGIA; MINISTÉRIO DA INDÚSTRIA E COMÉRCIO. [Ofício] 12 fev.. 1973, Brasília [para] Presidência da República. 1f. Relatório sobre estudos e intercâmbios técnicos com a Bolívia. In: Arquivo Nacional. Acervo referente à ditadura militar brasileira. Brasília: Arquivo Nacional, 2017b, p. 01.

37 EMBAIXADA DO BRASIL NA BOLÍVIA. [Dossiê] [?] 1972, La Paz [para] Ministério de Relações Exteriore do Brasil. Brasília. 66f. Relação Brasil/Bolívia. In: Arquivo Nacional - Ministério da Justiça e Segurança Pública. Acervo da Ditadura Militar. Brasília: Arquivo Nacional, 2017a, p. 57.
} 
DE SOUZA, Eliton Felipe. A disputa hegemônica brasileira com a república da argentina - o caso da ingerência na Bolívia. Revista Eletrônica Direito e Política, Programa de Pós-Graduação Stricto Sensu em Ciência Jurídica da UNIVALI, Itajaí, v.14, n.1, $1^{0}$ quadrimestre de 2019. Disponível em: www.univali.br/direitoepolitica - ISSN 1980-7791

Mais adiante, o documento relembra o Convênio de Tráfego Recíproco e Intercâmbio de Material Rodante e de Tração assinado em 1966, e que dava aos vizinhos "maior fluidez no transporte entre Santa Cruz e Santos e a utilização de locomotivas e vagões brasileiros, por empréstimo, pelas ferrovias da rede oriental boliviana"38.

Esse convênio permitia aos bolivianos uma opção para o escoamento de seus produtos para além dos acordos realizados com os argentinos e, consequentemente, pesava a balança das disputas Brasil/Argentina de modo favorável aos brasileiros que ampliaram as relações comerciais com a Bolívia e reduziram a importância argentina na região.

No entanto, como o documento ainda aponta, no início da década de 1970, esse convênio parecia dar sinais de esgotamento em relação às intenções brasileiras:

Malgrado todas essas facilidades, a zona oriental da Bolívia pouco se vinha utilizando da via Corumbá-Santos para o seu intercâmbio com o exterior, recorrendo para isso, às ferrovias e portos argentinos e, residualmente, aos serviços chilenos e peruanos. Devia-se isso, às altas taxas das ferrovias e portos brasileiros, que, no caso da das exportações de algodão boliviano, superavam em 11 dólares por tonelada as taxas argentinas.

Da mesma forma, a Argentina procurava outras maneiras de se atrelar à economia boliviana. Em 1969, o Ministério de Relações Exteriores e Culto de Buenos Aires produziu o Informativo Relativo al Plan de Obras del Rio Bermejo39. Essas obras vinham sendo planejadas desde $1967^{40}$ e seriam uma importante rota de escoamento de mercadorias não só entre os dois países, mas também para Chile, Uruguai e Paraguai, "con lo que pasa a ser una realidad la intercomunicación ferrofluvial, atlântico-Pacífico"41. Além disso, possibilitaria à Argentina ampliar a agricultura do país, pois cerca de $648.000 \mathrm{~km}^{2}$ da zona de influência das obras

38 EMBAIXADA DO BRASIL NA BOLÍVIA. [Dossiê] [?] 1972, La Paz [para] Ministério de Relações Exteriore do Brasil. Brasília. 66f. Relação Brasil/Bolívia. p. 58.

${ }^{39}$ Com $1.450 \mathrm{~km}$, o río Bermejo nasce nas serras bolivianas de Santa Victoria e desemboca no río Paraguai, tendo sua maior parte em território argentino.

40 MINISTÉRIO DAS RELAÇÕES EXTERIORES E CULTO DA ARGENTINA - SUBSECRETARÍA DE RELAÇÕES EXTERIORES. [Ofício] 25 jan. 1967, Buenos Aires. [para] Asesoría General de Planeamiento de Argentina. Buenos Aires. 2f. Corresponde a nota No 21 Reservada de la Comisión Nacional del Rio Bermejo, de fecha 25 de enero de 1967. In: Archivo de Cancillería. Acervo referente ao Cone Sul. Buenos Aires: Archivo de Cancillería, 2018.

41 MINISTÉRIO DAS RELAÇÕES EXTERIORES E CULTO DA ARGENTINA. [Estudo] 22 jun. 1969, Buenos Aires. [para] Asesoría General de Planeamiento de Argentina. Buenos Aires. 6f. Informativo Relativo al Plan de Obras del Rio Bermejo. In: Archivo de Cancillería. Acervo referente ao Cone Sul. Buenos Aires: Archivo de Cancillería, 2018, p. 02. 
DE SOUZA, Eliton Felipe. A disputa hegemônica brasileira com a república da argentina - o caso da ingerência na Bolívia. Revista Eletrônica Direito e Política, Programa de Pós-Graduação Stricto Sensu em Ciência Jurídica da UNIVALI, Itajaí, v.14, n.1, 10 quadrimestre de 2019. Disponível em: www.univali.br/direitoepolitica - ISSN 1980-7791

estavam desabitadas e já se tinha confirmado que "más de 120 productos agrícolas pueden producirse en esos solos donde la ganadería se desarrolla con una gran variedad de pasturas naturales" ${ }^{\prime 42}$.

O governo argentino oferecia, ainda, auxílio técnico ao governo boliviano: em abril de 1972, engenheiros bolivianos do Serviço Nacional de Estradas, da Corporação Boliviana de Fomento e do Comando de Engenharia do Exército foram convidados pela Direção Nacional de Estradas da Argentina para o Seminário de Engenharia de Pontes e visitas a grandes estruturas, com duração de três semanas ${ }^{43}$.

Menos de um ano antes, em julho de 1971, por iniciativa do Itamaraty, ocorreram reuniões da Comissão Mista Brasileiro-Boliviana de Cooperação Econômica e Técnica na tentativa de ampliar as relações econômicas entre os dois países e aumentar o intercâmbio de mercadorias. Essas reuniões parecem ter ampliado a confiança boliviana no governo brasileiro. Prova disso é que em dezembro de 1971, a embaixada brasileira em La Paz enviou um memorando à Secretaria de Estado das Relações Exteriores no qual informava sobre a reunião da Comissão Mista Bolívia-Argentina que ocorreria no dia 06 daquele mês. Segundo a representação brasileira, o chanceler boliviano garantiu que não trataria "da eventual construção da Ferrovia Santa Cruz-Cochabamba [...] declarando que essa construção tem de ser feita com o Brasil e não com a Argentina"44.

Além disso, foram adotadas medidas de racionalização e redução das taxas brasileiras, tornando o Brasil responsável pelo escoamento de $30 \%$ da produção algodoeira boliviana já em 1972. Essas reuniões previram, ainda, uma "participação substancial, também, no transporte de açúcar, madeiras e outros produtos de exportação do Oriente Boliviano"45.

42 MINISTÉRIO DAS RELAÇÕES EXTERIORES E CULTO DA ARGENTINA. [Estudo] 22 jun. 1969, Buenos Aires. [para] Asesoría General de Planeamiento de Argentina. Buenos Aires. $6 \mathrm{f}$. Informativo Relativo al Plan de Obras del Rio Bermejo. p. 03.

43 SERVICIO NACIONAL DE CAMINOS DE BOLÍVIA - DIVISÃO DE PLANEJAMENTO; DIVISÃO DE CONSTRUÇÕES; DIVISÃO DE PONTES. [Relatório] mai. 1972, La Paz. [para] Servicio Nacional de Caminos de Bolívia. La Paz.11f. Informe sobre el seminario de puentes y visita a obras realizado en la Reublica Argentina.. In: Archivo de Cancillería. Acervo referente ao Cone Sul. Buenos Aires: Archivo de Cancillería, 2018.

44 EMBAIXADA DO BRASIL NA BOLÍVIA. [Memorando] 01 dez. 1971, La Paz. [para] Secretaria de Estado das Relações Exteriores do Brasil. Brasília D.F.. 1f. Acordo comercial Bolívia-Argentina. Ferrovia Santa Cruz-Cochabamaba. In: Coordenação-Geral de Documentação Diplomática (CDO) do Ministério das Relações Exteriores. Acervo referente às embaixadas brasileiras. Brasília: Arquivo do Itamaraty, 2017b.

45 SERVICIO NACIONAL DE CAMINOS DE BOLÍVIA - DIVISÃO DE PLANEJAMENTO; DIVISÃO DE CONSTRUÇÕES; DIVISÃO DE PONTES. [Relatório] mai. 1972, La Paz. [para] Servicio Nacional de Caminos de Bolívia. La Paz.11f. Informe sobre el seminario de puentes y visita a obras realizado en la Reublica Argentina.. In: Archivo de Cancillería. Acervo referente ao Cone Sul. Buenos Aires: Archivo de Cancillería, 2018, p. 06. 
DE SOUZA, Eliton Felipe. A disputa hegemônica brasileira com a república da argentina - o caso da ingerência na Bolívia. Revista Eletrônica Direito e Política, Programa de Pós-Graduação Stricto Sensu em Ciência Jurídica da UNIVALI, Itajaí, v.14, n.1, 10 quadrimestre de 2019. Disponível em: www.univali.br/direitoepolitica - ISSN 1980-7791

Outrossim, ao mesmo tempo em que La Paz propunha à ditadura brasileira a venda de hidrocarbonetos e derivados, Brasília não só se propôs a estudar esta possibilidade, como se prontificou a criar facilidades para que "un grupo de representantes de empresas mineras estatales y privadas bolivianas visite los centros industriales brasileños afin de celebrar conversaciones con importadores y empresarios del sector de minerales y metales, [...] para los cuales existe mercado potencial en Brasil"46.

Sobre as ligações rodoviárias, em 1972, o Brasil possuía cinco rodovias fronteiriças com a Bolívia, no entanto, o prolongamento destas em território boliviano não passava de 90 quilômetros e a maioria delas estavam em péssimas condições de tráfego, levando o governo brasileiro a agir. Em setembro de 1971, Brasília se comprometeu a construir uma ponte internacional sobre o rio Mamoré; realizar os estudos e o projeto de engenharia da rodovia La Paz-Cobija; realizar a pavimentação da rodovia Guajará-Mirim-Abunã-Porto Velho, em um prazo máximo de dez anos. Nos três casos, não haveria ônus ao governo da bolívia ${ }^{47}$.

O documento de 1972 recomendava diversas novas construções, entre elas o acesso a Rodovia Ramón Gomez, sobre o arroio Conceição, construída em 04 de abril daquele ano. Essa seria a conexão entre a cidade de Miranda, na Bolívia, e Corumbá, no estado do Mato Grosso do Sul, pela BR 262.

Da mesma forma, a ditadura brasileira mantinha estreitos laços diplomáticos com o país vizinho. Em outubro de 1981, a chancelaria boliviana solicitou a ajuda brasileira para a aprovação durante a XII Reunião de chanceleres da bacia do Prata, para o projeto de aproveitamento das águas do rio Pilcomayo em obras de irrigação, produção de energia, controle de erosão e sedimentação ${ }^{48}$. Em 02 de dezembro daquele mesmo ano, também, a embaixada boliviana, em Brasília, enviou ofício à chancelaria brasileira agradecendo ao "apoyo prestado a la solicitud boliviana para incluir en la Agenda del XI Período Ordinario de Sesiones de la Asembleia General de la OEA el tema relativo al "Problema marítimo de Bolivia"49.

46 MINISTÉRIO DAS RELAÇÕES EXTERIORES E CULTO DA BOLÍVIA. [Memorando] 25 de setembro 1971, La Paz [para] Ministério de Relações Exteriore do Brasil. Brasília. 02f. Resposta do governo boliviano às requisições brasileiras durante a Primeira Reunião da Comissão Mista Brasileira-boliviana de Cooperação Econômica e Técnica. In: Arquivo Nacional - Ministério da Justiça e Segurança Pública. Acervo da Ditadura Militar. Brasília: Arquivo Nacional, 2017, p. 01.

47 EMBAIXADA DO BRASIL NA BOLÍVIA. [Dossiê] [?] 1972, La Paz [para] Ministério de Relações Exteriore do Brasil. Brasília. 66f. Relação Brasil/Bolívia. In: Arquivo Nacional - Ministério da Justiça e Segurança Pública. Acervo da Ditadura Militar. Brasília: Arquivo Nacional, 2017c, p. 60.

48 EMBAIXADA DA BOLÍVIA NO BRASIL. [Memorando] 27 out. 1981, Brasília D.F. [para] Ministério de Relações Exteriores do Brasil. Brasília D.F.. 1f. Pedido de apoio à Bolívia na XII Reunião de Chanceleres da Bacia do Prata. In: Coordenação-Geral de Documentação Diplomática (CDO) do Ministério das Relações Exteriores. Acervo referente às embaixadas brasileiras. Brasília: Arquivo do Itamaraty, 2017a.

49 EMBAIXADA DA BOLÍVIA NO BRASIL. [Ofício] 02 dez. 1981, Brasília D.F. [para] Ministério de Relações Exteriores do Brasil. Brasília D.F.. 1f. Questão mediterrânea boliviana. In: Coordenação- 
DE SOUZA, Eliton Felipe. A disputa hegemônica brasileira com a república da argentina - o caso da ingerência na Bolívia. Revista Eletrônica Direito e Política, Programa de Pós-Graduação Stricto Sensu em Ciência Jurídica da UNIVALI, Itajaí, v.14, n.1, $1^{0}$ quadrimestre de 2019. Disponível em: www.univali.br/direitoepolitica - ISSN 1980-7791

O documento demonstra a gratidão pelos esforços brasileiros para o escoamento das mercadorias bolivianas pelo oceano. A ditadura brasileira, inclusive, agia constantemente na disputa boliviana com o Chile, sobre a questão marítima. Nesse último documento, a chancelaria do país andino considerava "altamente significativo para el gobierno de Bolivia la disposición del ilustrado Gobierno del Brasil de acompañar con sumo interés los esfuerzos que se vienen realizando para lograr una solución satisfactoria a la mediterraneidad boliviana".

Esse frequente apoio se tornara indispensável para a ditadura brasileira manter uma contínua vigília sobre o cenário político boliviano, assim como sobre as relações internacionais daquele país. É comum, por exemplo, encontrar documentos como o intitulado Relações Bolívia Chile, ${ }^{50}$ produzido em fins da década de 1960 e que traçava um histórico das relações entre os dois países vizinhos na perspectiva de uma visita do mandatário chileno, Eduardo Frei Montalva, à Brasília, tendo o Brasil o papel de mediador da questão marítima.

Da mesma forma, em 1973, o Conselho de Segurança Nacional, aproveitando as negociações entre a diplomacia brasileira e a boliviana na questão dos hidrocarbonetos, elaborara um relatório intitulado Aspectos políticos e militares da Bolívia ${ }^{51}$, este contém informações a respeito do governo do então presidente Hugo Banzer e das medidas políticas adotadas no interior das FFAA do país.

Outrossim, a subsecretaria Geral do Conselho de Segurança Nacional demonstrava preocupação com a posição de setores políticos e da opinião pública que tendiam a apoiar uma aproximação boliviana ao governo argentino. De acordo com o documento, "nos meios políticos e militares bolivianos identificam-se duas linhas de opinião distintas, uma tendente a uma maior aproximação com o brasil, enquanto a outra tende para a Argentina". Para o CSN essa aproximação se dava, em grande medida, pela ação de militares estrangeiros em território boliviano, o que fazia a balança pender contra o Brasil, já que "sob este aspecto a Marinha argentina leva uma grande vantagem, por contar com uma missão naval na Bolívia, composta de significativo número de militares".

Geral de Documentação Diplomática (CDO) do Ministério das Relações Exteriores. Acervo referente às embaixadas brasileiras. Brasília: Arquivo do Itamaraty, 2017b.

50 EMBAIXADA DO BRASIL NA BOLÍVIA. [Memorando] [entre 1964 e 1970], Laz Paz [para] Ministério das Relações Exteriores do Brasil. Brasília D.F.. 2f. Relações Bolívia Chile.In: Arquivo Nacional Ministério da Justiça e Segurança Pública.. Acervo da Ditadura Militar. Brasília: Arquivo Nacional, 2017d, p. 01-02.

51 SECRETARIA GERAL DO CONSELHO DE SEGURANÇA NACIONAL. [Memorando] 05 jun. 1973, Laz Paz [para] Secretário Geral do Conselho de Segurança Nacional. Brasília D.F.. 4f. Aspectos políticosmilitares da Bolívia.In: Arquivo Nacional - Ministério da Justiça e Segurança Pública. Acervo da Ditadura Militar. Brasília: Arquivo Nacional, 2017, p. 01-04. 
DE SOUZA, Eliton Felipe. A disputa hegemônica brasileira com a república da argentina - o caso da ingerência na Bolívia. Revista Eletrônica Direito e Política, Programa de Pós-Graduação Stricto Sensu em Ciência Jurídica da UNIVALI, Itajaí, v.14, n.1, $1^{0}$ quadrimestre de 2019. Disponível em: www.univali.br/direitoepolitica - ISSN 1980-7791

O acordo que deu origem à missão naval argentina na Bolívia, foi firmado em setembro de 1964, mas só seria efetivado em 1970. A missão tinha como objetivo "prestar el asesoramiento técnico profesional a la Fuerza Naval Boliviana en todo lo relativo a problemas y asuntos navales" 52 .

Mesmo com a ditadura brasileira trabalhando constantemente para reduzir a aproximação entre Bolívia e Argentina e para garantir a preponderância brasileira sobre os negócios bolivianos, a vigilância sobre a política externa boliviana era contínua e sempre demonstrando preocupação do lado brasileiro. Em 1978, o chefe da Divisão da América Meridional do Ministério das Relações Exteriores, Rubens Ricupero, enviou um telegrama ao diretor da Petrobras, Paulo Vieira Bellotti, expressando apreensão em relação a possibilidade do aumento de "quase 100 por cento [n]o volume d[as] vendas de gás à Argentina que passariam de quatro e meio milhões de metros cúbicos para cerca de oito e meio milhões" podendo comprometer negociações de aumento na venda de gás ao Brasil.

Outra fonte de oposição aos brasileiros estava no jornal Presencia. Segundo o CSN, o periódico fazia "uma sistemática campanha anti-brasileira, através de inserção de pequenas notícias que procuram contestar o desenvolvimento nacional, principalmente no que se refere a contenção da inflação e ao bem estar do povo". Em editorial de agosto de 1970, aparece o apoio a colaboração Argentino-boliviana às iniciativas argentinas de cooperação com La Paz para a construção de escolas técnicas ${ }^{53}$. O texto dizia que a ação de Buenos Aires: "es una de las pruebas más objetivas de la preocupación del país vecino por contribuir a nuestro desarrollo integral y equilibrado [...], constituyendo una muestra más, de los lazos de amizade que nos unen". De fato, em 1974, seria entregue a escola General Manuel Belgrano, na cidade de Tarija, Sul da Bolívia, "teniendo en cuenta que el Gobierno de la República Argentina ha concluído la construción y equipamiento del edificio y que por Decreto Supremo No 192 del 22 de Febrero de 1974 ha donado el mismo al Gobierno de la República de Bolivia, quién aceptó la donacion por D.S. No 11530 de fecha 14 de junio de $1974^{\prime \prime 54}$.

52 MINISTÉRIO DAS RELAÇÕES EXTERIORES E CULTO DA BOLÍVIA; MINISTÉRIO DAS RELAÇÕES EXTERIORES E CULTO DA ARGENTINA. Acuerdo boliviano-argentino para el establecimiento de una mision naval argentina en la Republica de Bolívia. La Paz, 1970. In: Archivo de Cancilleria. Acervo referente ao Cone Sul. Buenos Aires: Archivo de Cancillería, 2018.

53 EMBAIXADA DA BOLÍVIA NA ARGENTINA. [Informativo] 27 ago. 1970, Buenos Aires. [para] Ministério das Relações Exteriores e Culto da Bolívia. La Paz. 1f. Editorial del matutino "Presencia" titulado: "Importância de escuelas técnicas en nuestro país". In: Archivo de Cancillería. Acervo referente ao Cone Sul. Buenos Aires: Archivo de Cancillería, 2018.

54 EMBAIXADA DA ARGENTINA NA BOLÍVIA. Archivo de Cancillería. Acta de entrega de la "esculea argentina Manuel Belgrano realizada no dia 27 de agosto de 1974. Acervo referente ao Cone Sul. Buenos Aires: Archivo de Cancillería, 2018, p. 01. 
DE SOUZA, Eliton Felipe. A disputa hegemônica brasileira com a república da argentina - o caso da ingerência na Bolívia. Revista Eletrônica Direito e Política, Programa de Pós-Graduação Stricto Sensu em Ciência Jurídica da UNIVALI, Itajaí, v.14, n.1, $1^{0}$ quadrimestre de 2019. Disponível em: www.univali.br/direitoepolitica - ISSN 1980-7791

As embaixadas brasileiras em outros países eram informadas e preparadas para se posicionarem em relação ao que se passava em meio ao governo boliviano. Em 02 de fevereiro de 1970, um memorando do Ministério de Relações Exteriores demonstrava inquietação sobre as eleições bolivianas daquele ano. De acordo com o documento, durante o governo do General Alfredo Ovando Candia, as mesmas pressões sofridas pela ditadura brasileira para fornecer armas e apoio logístico contra os focos guerrilheiros na Bolívia, ocorriam com o governo argentino. A chancelaria afirmava que a estrutura política de Candia estava dividida entre duas facções: uma à esquerda e outra à direita e que o presidente se equilibrava entre esses dois grupos para permanecer no poder. Nas eleições daquele ano, vencidas por Juan José Torres Gonzáles, portanto, estava em jogo uma transformação à esquerda por parte do governo boliviano e a ditadura brasileira estava pronta para barrar essa mudança 55 .

Segundo o memorando, caso as embaixadas fossem questionadas sobre a posição brasileira, a resposta deveria ser:

1) [...] Vemos com legítima preocupação o desenvolvimento da situação boliviana, no sentido de que possa esse país amigo estar sendo vítima de uma conspiração Castrocomunista que, se vencedora, colocarah (Sic.) em antagonismo com governo brasileiro, cujas bases filosóficas não se compadecem com o comunismo [...] 2) que na hipótese acima considerado o governo brasileiro não poderah (Sic.) deixar avolumar-se uma frente hostil e empregaram o melhor de seus esforços no sentido de impedir a formação de qualquer influência perturbadora da tranquilidade de suas populações fronteiriças [...] 3) na condição de que esta eh (Sic.) também a posição desse governo, o governo brasileiro deseja manter a mais estreita e constante troca de informações com governo argentino.

De fato, a eleição do presidente Torres fez com que a ditadura brasileira se movimentasse para apoiar iniciativas de golpe de Estado, bem como a organização de uma rede de informações sobre a situação política boliviana.

A Bolívia era de interesse de Brasil e Argentina, mas, também, alvo de conversas entre Nixon e Médici em dezembro de 1971. Em reunião na Casa Branca, o ditador brasileiro relatara ao presidente dos Estados Unidos que agia "dentro do limite de

55 MINISTÉRIO DAS RELAÇÕES EXTERIORES. [Memorando] 02 fev.. 1970, Brasília D.F. [para] Embaixada brasileira em Buenos Aires. Brasília D.F.. 2f. Relações Brasil-Bolívia. In: CoordenaçãoGeral de Documentação Diplomática (CDO) do Ministério das Relações Exteriores. Acervo referente às embaixadas brasileiras. Brasília: Arquivo do Itamaraty, 2017. 
DE SOUZA, Eliton Felipe. A disputa hegemônica brasileira com a república da argentina - o caso da ingerência na Bolívia. Revista Eletrônica Direito e Política, Programa de Pós-Graduação Stricto Sensu em Ciência Jurídica da UNIVALI, Itajaí, v.14, n.1, $1^{0}$ quadrimestre de 2019. Disponível em: www.univali.br/direitoepolitica - ISSN 1980-7791

seus recursos [...] tentando ajudar seus vizinhos, particularmente a Bolívia, que estava em dificuldades realmente desesperadoras". Sem especificar quem, Médici afirmou ter recebido a visita "de um Ministro do Gabinete boliviano que pediu 30.000 toneladas de açúcar, para começar a pagar após um período de três anos, podendo ser estendido por mais de dez anos". Tal pedido foi recusado, mas "o ministro boliviano disse que isso não era uma venda normal; se houvesse escassez de açúcar na Bolívia, o governo cairia e a extrema esquerda assumiria o controle". Médici, teria acatado o pedido, emitindo "instruções para que o açúcar fosse disponibilizado nestes termos. para os bolivianos". Não satisfeito, o ministro boliviano fez outro pedido sob os mesmos termos: "dez caças a jato brasileiros Xavantes". O que deixara o mandatário indignado pois era "ridículo que um país que estava com dificuldades econômicas estivesse comprando caças a jato". Médici acrescentou que tinha muita dificuldade em "lidar e compreender a mentalidade hispano-americana" e sentia que deveria ser ainda mais difícil para o presidente Nixon. O general brasileiro finalizou "dizendo ironicamente que o Brasil e os Estados Unidos tinham dificuldades em lidar com os latino-americanos: isto é, que os brasileiros falavam português e os americanos inglês" (nossa tradução) ${ }^{56}$.

De forma subjetiva, a fala de Nixon evidencia um sentimento de igualdade de forças em relação ao presidente dos Estados Unidos, da mesma forma que demonstra a posição brasileira de não se encaixar como país latino-americano a partir de uma pretensa superioridade. Acontece que com a chegada dos militares ao poder no Brasil, em 1964, as ações do governo foram elevadas a outro nível, fazendo com que, não só a Bolívia, mas Paraguai, Chile e Uruguai passassem a gravitar cada vez mais na órbita brasileira.

\section{CONSIDERAÇÕES FINAIS}

Quando Eduardo Galeano escreveu As veias abertas da América Latina, em 1971, utilizou dados econômicos, históricos e sociais dos 500 anos da chegada dos europeus ao continente. O autor uruguaio não deixou de abordar o papel dos governos instituídos na região no processo de exploração de seus próprios povos, além das disputas hegemônicas sobre as nações mais débeis. No entanto, a imagem de um continente submetido à vassalagem internacional e à constante destruição de suas riquezas naturais e culturais destaca-se e é o que a maioria dos leitores retém da leitura.

\footnotetext{
56 KISSINGER, Henry. [Memorando] 09 dez. 1971, Washington D.C [para] Arquivo presidencial. Washington, D.C. 7f. Meeting with the President Emílio Garrastazú Médici of Brazil on Thursday, decembre 9, 1971 at 10:00 a.m., in the President's Offici, the White House. In: Digital National Security Archive (DNSA). Acervo Brazil Conspired with U.S. to Overthrow Allende. Washington D.C.: The National Security Archive, 2017a, p. 04.
} 
DE SOUZA, Eliton Felipe. A disputa hegemônica brasileira com a república da argentina - o caso da ingerência na Bolívia. Revista Eletrônica Direito e Política, Programa de Pós-Graduação Stricto Sensu em Ciência Jurídica da UNIVALI, Itajaí, v.14, n.1, $1^{0}$ quadrimestre de 2019. Disponível em: www.univali.br/direitoepolitica - ISSN 1980-7791

Contudo, as forças internas de dominação na América Latina não deixaram de estar presentes no processo que Galeano denunciou. Uma das discussões que parece ter influenciado o autor foi aquela derivada dos debates da Teoria da Dependência em torno do "subimperialismo", como um imperialismo de segundo grau, na participação de soldados paraguaios na República Dominicana, em 1965, a mando do governo estadunidense e sob o comando de um general brasileiro ${ }^{57}$; e que a intenção subimperialista no Brasil dos militares sobre os vizinhos. "Um elenco militar de [...] postula o país como o grande administrador dos interesses norte-americanos na região, e chama o Brasil para exercer, no Sul, uma hegemonia semelhante a que, frente aos Estados Unidos, o próprio Brasil padece $^{\prime \prime 58}$.

Em tal relação de poder, Brasília impunha ao governo boliviano os interesses nacionais brasileiros. Com o advento da ditadura e das constantes intervenções políticas na Bolívia, os tratados internacionais que como afirma Tolfo "são utilizados para elaborar normas de convivência entre os povos"59, passou a figurar como mais um mecanismo de controle por parte do Brasil.

Pode-se afirmar, então, que o conceito de subimperialismo formulado por Marini, pode nos dar respostas sobre o modelo político levado a cabo no Brasil dos generais. Como demonstrado em alguns pontos fundamentais dessa categoria, como uma relativa autonomia para políticas externas em relação aos centros imperialistas; alianças entre a burguesia nacional aproximando-se do Estado e ampliando mercados externos; e utilização dos mercados para resolver os problemas relacionados de acumulação de capital. A agência desses grupos, no entanto, só poderia existir a partir da colaboração entre as classes dominantes "para contener la ascensión revolucionaria de las masas [...] y que sólo puede agravarse con la marcha de la integración imperialista"60.

Nesse artigo foram apresentados elementos mobilizados pela ditadura brasileira na pretensão hegemônica sul-americana configurando relações de dependência e dominação nas correlações internas, atentando para as estratégias nacionais de desenvolvimento capitalista brasileiras que atentaram contra a ordem jurídica internacional, desrespeitando a soberania externa boliviana, já que, como afirma

57 GALEANO, Eduardo. As veias abertas da América Latina. Porto Alegre: L\&PM, 2010, p. 138.

58 GALEANO, Eduardo. As veias abertas da América Latina. p. 182.

59 TOLFO, Andreia Cadore. A origem da previsão constitucional da participação do poder legislativo na conclusão dos tratados internacionais. Revista Eletrônica Direito e Política, Programa de PósGraduação Stricto Sensu em Ciência Jurídica da UNIVALI, Itajaí, v.8, n.3, 30 quadrimestre de 2013. Disponível em: www.univali.br/direitoepolitica, p. 1730.

60 MARINI, Ruy Mauro. La dialéctica del desarrollo capitalista en Brasil (1966), p. 78. 
DE SOUZA, Eliton Felipe. A disputa hegemônica brasileira com a república da argentina - o caso da ingerência na Bolívia. Revista Eletrônica Direito e Política, Programa de Pós-Graduação Stricto Sensu em Ciência Jurídica da UNIVALI, Itajaí, v.14, n.1, $1^{0}$ quadrimestre de 2019. Disponível em: www.univali.br/direitoepolitica - ISSN 1980-7791

Philippi essa soberania "significa que, nas relações recíprocas entre os Estados, não há subordinação nem dependência, e sim igualdade" 61 , o que, como demonstrado nesse artigo, não ocorre na relação de força estabelecida pelo Brasil.

Fica claro que entre a exploração imperialista dos Estados Unidos e os golpes militares na América Latina havia políticas de Estado internas que ambicionavam o papel de potência regional. Tal assertiva se evidencia quando estudamos as relações políticas entre Brasil, Argentina e Bolívia, produzido pelas chancelarias destes países. São centenas de documentos que revelam os interesses por trás do jogo político internacional e demonstram as táticas de Estado, utilizadas principalmente, pelo governo ditatorial brasileiro.

A ditadura brasileira agiu desestabilizando governos bolivianos, forçando acordos econômicos e asfixiando tentativas de políticas econômicas independentes, para se sobressair como a grande potência regional. Durante o período os intentos de conquista e controle da América do Sul estavam presentes e existiam como política de Estado, agudizando as disputas regionais.

Essas ações ocorreram sob o conhecimento e a conivência do governo dos Estados Unidos e o Brasil atuou na América do Sul como representante dos interesses imperialistas estadunidenses. Coube à ditadura brasileira fazer "'o trabalho sujo'", e assumir "grandes responsabilidades". O presidente Nixon, pessoalmente, "teria solicitado o apoio do general Medici em lidar com a segurança interna e o status quo no hemisfério, incluindo os governos da Bolívia e do Uruguai". Pedido aceito pelo ditador brasileiro, "uma vez que ele pessoalmente acredita que o governo brasileiro deve assumir um papel maior na defesa de governos vizinhos e amigáveis" ${ }^{\prime \prime 2}$.

Essa relação entre os dois colegas era uma via de mão dupla: enquanto o Brasil trabalhava para evitar possíveis governos de esquerda ou de um capitalismo independente aos Estados Unidos, os aliados do Norte garantiam à ditadura brasileira a independência regional em um imperialismo de segunda classe que se

\footnotetext{
61 PHILIPPI, Patricia Pasqualini; ZICARELLI, Leonardo. O direito transnacional ambiental e a proteção do direito ao desenvolvimento humano. Revista Eletrônica Direito e Política, Programa de PósGraduação Stricto Sensu em Ciência Jurídica da UNIVALI, Itajaí, v.8, n.3, 30 quadrimestre de 2013. Disponível em: www.univali.br/direitoepolitica, p. 1610-1611.

62 DEPARTAMENTO DE ESTADO DOS ESTADOS UNIDOS DA AMÉRICA. [Memorando] 29 dez. 1971, Washington D.C. [para] Departamento de Estado dos Estados Unidos da América. Washington D.C. 2f. Alegados compromissos do presidente Richard M. Nixon ao presidente brasileiro, Emílio Garrastazu Médici [nossa tradução]. In: Digital National Security Archive (DNSA). Acervo Brazil Conspired with U.S. to Overthrow Allende. Washington D.C.: The National Security Archive, 2017. Disponível em
} <https://nsarchive2.gwu.edu//NSAEBB/NSAEBB282/Document\%20145\%2012.29.71.pdf> acessado em 02/02/2018, p. 02. 
DE SOUZA, Eliton Felipe. A disputa hegemônica brasileira com a república da argentina - o caso da ingerência na Bolívia. Revista Eletrônica Direito e Política, Programa de Pós-Graduação Stricto Sensu em Ciência Jurídica da UNIVALI, Itajaí, v.14, n.1, $1^{0}$ quadrimestre de 2019. Disponível em: www.univali.br/direitoepolitica - ISSN 1980-7791

estendia sob os países vizinhos. Dois documentos ${ }^{6364}$ de 1971 indicam que para os Estados Unidos, o Brasil podia encontrar-se em uma posição respeitada e admirada e que o ditador brasileiro era um valioso aliado para ser consultado antes das viagens de Nixon a Pequim e Moscou.

Fica claro, portanto, que o governo brasileiro era incapaz de fazer frente ao poder político, econômico e militar estadunidense, dado, principalmente, a sua economia altamente dependente do capital estrangeiro, contudo, havia por parte dos Estados Unidos o reconhecimento do Brasil como potência regional capaz de auxiliar na manutenção do modo de produção capitalista na América do Sul. A própria cúpula do poder da Casa Branca, incluindo o presidente Nixon, viam Médici como importante aliado.

\section{REFERÊNCIAS DAS FONTES CITADAS}

DEPARTAMENTO DE ESTADO DOS ESTADOS UNIDOS DA AMÉRICA. [Memorando] 29 dez. 1971, Washington D.C. [para] Departamento de Estado dos Estados Unidos da América. Washington D.C. 2f. Alegados compromissos do presidente Richard M. Nixon ao presidente brasileiro, Emílio Garrastazu Médici [nossa tradução]. In: Digital National Security Archive (DNSA). Acervo Brazil Conspired with U.S. to Overthrow Allende. Washington D.C.: The National Security Archive, $2017 . \quad$ Disponível em <https://nsarchive2.gwu.edu//NSAEBB/NSAEBB282/Document\%20145\%2012.2 9.71.pdf > acessado em 02/02/2018, p. 02.

EMBAIXADA DA ARGENTINA NA BOLÍVIA. Archivo de Cancillería. Acta de entrega de la "esculea argentina Manuel Belgrano realizada no dia 27 de agosto de 1974. Acervo referente ao Cone Sul. Buenos Aires: Archivo de Cancillería, 2018, p. 01.

EMBAIXADA DA BOLÍVIA NO BRASIL. [Memorando] 27 out. 1981, Brasília D.F. [para] Ministério de Relações Exteriores do Brasil. Brasília D.F.. 1f. Pedido de apoio à Bolívia na XII Reunião de Chanceleres da Bacia do Prata. In: Coordenação-Geral

\footnotetext{
63 KISSINGER, Henry. [Memorando] 09 dez. 1971, Washington D.C [para] Arquivo presidencial. Washington, D.C. 7f. Meeting with the President Emílio Garrastazú Médici of Brazil on Thursday, decembre 9, 1971 at 10:00 a.m., in the President's Offici, the White House. In: Digital National Security Archive (DNSA). Acervo Brazil Conspired with U.S. to Overthrow Allende. Washington D.C.: The National Security Archive, 2017a.

${ }^{64}$ KISSINGER, Henry. [Memorando] 13 nov. 1971, Washington D.C. [para] Arnoldo Nachmanoff. Washington D.C. 05f. Your meeting with President Emílio Garrastazu Médici of Brazil, Wednesday, December 8, 1971, 05:15 p.m. Blair House. In: Digital National Security Archive (DNSA). Acervo Nixon: "Brazil helped rig the Urugayan elections," 1971. Washington D.C.: The National Security Archive, 2017b.
} 
DE SOUZA, Eliton Felipe. A disputa hegemônica brasileira com a república da argentina - o caso da ingerência na Bolívia. Revista Eletrônica Direito e Política, Programa de Pós-Graduação Stricto Sensu em Ciência Jurídica da UNIVALI, Itajaí, v.14, n.1, $1^{0}$ quadrimestre de 2019. Disponível em: www.univali.br/direitoepolitica - ISSN 1980-7791

de Documentação Diplomática (CDO) do Ministério das Relações Exteriores. Acervo referente às embaixadas brasileiras. Brasília: Arquivo do Itamaraty, 2017a.

- [Ofício] 02 dez. 1981, Brasília D.F. [para] Ministério de Relações Exteriores do Brasil. Brasília D.F.. 1f. Questão mediterrânea boliviana. In: Coordenação-Geral de Documentação Diplomática (CDO) do Ministério das Relações Exteriores. Acervo referente às embaixadas brasileiras. Brasília: Arquivo do Itamaraty, 2017b.

EMBAIXADA DO BRASIL NA BOLÍVIA. [Memorando] 01 dez. 1971, La Paz. [para] Secretaria de Estado das Relações Exteriores do Brasil. Brasília D.F.. 1f. Acordo comercial Bolívia-Argentina. Ferrovia Santa Cruz-Cochabamaba. In: CoordenaçãoGeral de Documentação Diplomática (CDO) do Ministério das Relações Exteriores. Acervo referente às embaixadas brasileiras. Brasília: Arquivo do Itamaraty, 2017b.

[Dossiê] [?] 1972, La Paz [para] Ministério de Relações Exteriore do Brasil. Brasília. 66f. Relação Brasil/Bolívia. In: Arquivo Nacional - Ministério da Justiça e Segurança Pública. Acervo da Ditadura Militar. Brasília: Arquivo Nacional, 2017a, p. 57.

. [Dossiê] [?] 1972, La Paz [para] Ministério de Relações Exteriore do Brasil. Brasília. 66f. Relação Brasil/Bolívia. In: Arquivo Nacional - Ministério da Justiça e Segurança Pública. Acervo da Ditadura Militar. Brasília: Arquivo Nacional, 2017c, p. 60.

. [Memorando] [entre 1964 e 1970], Laz Paz [para] Ministério das Relações Exteriores do Brasil. Brasília D.F.. 2f. Relações Bolívia Chile.In: Arquivo Nacional - Ministério da Justiça e Segurança Pública.. Acervo da Ditadura Militar. Brasília: Arquivo Nacional, 2017d, p. 01-02.

EMBAIXADA DO BRASIL NA BOLÍVIA - SECRETARIA DE ESTADO DAS RELAÇÕES EXTERIORES. [Telegrama] 03 ago. 1970, Brasília [para] II Seção do Estado Maior do Exército e II Seção do Estado Maior da Aeronáutica. Brasília. 2f. Situação político-militar na Bolívia. In: Arquivo Nacional - Ministério da Justiça e Segurança Pública. Acervo da Ditadura Militar. Brasília: Arquivo Nacional, 2017, p. 02.

EMBAIXADA DA BOLÍVIA NA ARGENTINA. [Informativo] 27 ago. 1970, Buenos Aires. [para] Ministério das Relações Exteriores e Culto da Bolívia. La Paz. 1f. Editorial del matutino "Presencia" titulado: "Importância de escuelas técnicas en nuestro país". In: Archivo de Cancillería. Acervo referente ao Cone Sul. Buenos Aires: Archivo de Cancillería, 2018. 
DE SOUZA, Eliton Felipe. A disputa hegemônica brasileira com a república da argentina - o caso da ingerência na Bolívia. Revista Eletrônica Direito e Política, Programa de Pós-Graduação Stricto Sensu em Ciência Jurídica da UNIVALI, Itajaí, v.14, n.1, $1^{0}$ quadrimestre de 2019. Disponível em: www.univali.br/direitoepolitica - ISSN 1980-7791

[Telegrama] 26 jun. 1971, Buenos Aires [para] Secretaria de Estado

das Relações Esteriores. Brasília. 5f. Argentina, política em relação ao Brasil. In: Coordenação-geral De Documentação Diplomática (CDO) do Ministério Das Relações Exteriores. Acervo referente às embaixadas brasileiras. Brasília: Arquivo do Itamaraty, 2017. p 01.

ESTADO MAIOR DAS FORÇAS ARMADAS. [Ofício] 03 out. 1970, Brasília [para] Secretário Geral de Segurança Nacional. Brasília. 3f. Aviso No 35 PA-2 267. In: Arquivo Nacional - Ministério da Justiça e Segurança Pública. Acervo da Ditadura Militar. Brasília: Arquivo Nacional, 2017, p. 03.

FICO, Carlos. Ditadura militar brasileira: aproximações teóricas e historiográficas. Revista Tempo e Argumento, Florianópolis, v. 9, n. 20, p. 05 - 74. jan./abr. 2017.

KISSINGER, Henry. [Memorando] 13 nov. 1971, Washington D.C. [para] Arnoldo Nachmanoff. Washington D.C. 05f. Your meeting with President Emílio Garrastazu Médici of Brazil, Wednesday, December 8, 1971, 05:15 p.m. Blair House. In: Digital National Security Archive (DNSA). Acervo Nixon: "Brazil helped rig the Urugayan elections," 1971. Washington D.C.: The National Security Archive, 2017b.

. [Memorando] 09 dez. 1971, Washington D.C [para] Arquivo presidencial. Washington, D.C. 7f. Meeting with the President Emílio Garrastazú Médici of Brazil on Thursday, decembre 9, 1971 at 10:00 a.m., in the President's Offici, the White House. In: Digital National Security Archive (DNSA). Acervo Brazil Conspired with U.S. to Overthrow Allende. Washington D.C.: The National Security Archive, 2017a.

LIMA, Rafael Teixeira de. Entre o imperialismo e o subimperialismo: a projeção brasileira à Bolívia e ao Peru nos governos Lula da Silva (2003-2010). Rebela. Florianópolis, v.6, n.3. set./dez. 2016, p. 530-545.

LUCE, Mathias Seibel. O subimperialismo, etapa superior do capitalismo dependente. Tensões mundiais. Fortaleza, v. 10, n. 18, 19, jun. 2014, p. 43-65.

A teoria do subimperialismo em Ruy Mauro Marini: contradições do capitalismo dependente e a questão do padrão de reprodução do capital. A história de uma categoria. 2011. 225. Tese (Doutorado em História) Programa de Pós-Graduação em História da Universidade Federal do Rio Grande do Sul (PPGHUFRGS), Porto Alegre, 2011.

MARIANO, Marcelo Passini. A política externa brasileira e a integração regional: uma análise a partir do Mercosul [online]. São Paulo: Editora UNESP, 2015. 
DE SOUZA, Eliton Felipe. A disputa hegemônica brasileira com a república da argentina - o caso da ingerência na Bolívia. Revista Eletrônica Direito e Política, Programa de Pós-Graduação Stricto Sensu em Ciência Jurídica da UNIVALI, Itajaí, v.14, n.1, $1^{0}$ quadrimestre de 2019. Disponível em: www.univali.br/direitoepolitica - ISSN 1980-7791

MARINI, Ruy Mauro. Dialéctica de la dependencia. 2. ed. México: Era, 1974.

La acumulación capitalista mundial y el subimperialismo. In: Cuadernos Políticos n 12. México: Ediciones Era, 1977.

. La dialéctica del desarrollo capitalista en Brasil (1966). In: MARTINS,

Carlos Eduardo. América Latina, dependencia y globalización/Ruy Mauro Marini: antología y presentación. México, D. F.: Siglo XXI; Buenos Aires: CLACSO, 2015, p. 107-151.

MINISTÉRIO DAS RELAÇÕES EXTERIORES. [Memorando] 02 fev.. 1970, Brasília D.F. [para] Embaixada brasileira em Buenos Aires. Brasília D.F.. 2f. Relações Brasil-Bolívia. In: Coordenação-Geral de Documentação Diplomática (CDO) do Ministério das Relações Exteriores. Acervo referente às embaixadas brasileiras. Brasília: Arquivo do Itamaraty, 2017.

MINISTÉRIO DAS RELAÇÕES EXTERIORES E CULTO DA ARGENTINA. [Estudo] 22 jun. 1969, Buenos Aires. [para] Asesoría General de Planeamiento de Argentina. Buenos Aires. 6f. Informativo Relativo al Plan de Obras del Rio Bermejo. In: Archivo de Cancillería. Acervo referente ao Cone Sul. Buenos Aires: Archivo de Cancillería, 2018, p. 02.

MINISTÉRIO DAS RELAÇÕES EXTERIORES E CULTO DA ARGENTINA SUBSECRETARÍA DE RELAÇÕES EXTERIORES. [Ofício] 25 jan. 1967, Buenos Aires. [para] Asesoría General de Planeamiento de Argentina. Buenos Aires. 2f. Corresponde a nota No 21 Reservada de la Comisión Nacional del Rio Bermejo, de fecha 25 de enero de 1967. In: Archivo de Cancillería. Acervo referente ao Cone Sul. Buenos Aires: Archivo de Cancillería, 2018.

MINISTÉRIO DAS RELAÇÕES EXTERIORES E CULTO DA BOLÍVIA; MINISTÉRIO DAS RELAÇÕES EXTERIORES E CULTO DA ARGENTINA. Acuerdo boliviano-argentino para el establecimiento de una mision naval argentina en la Republica de Bolívia. La Paz, 1970. In: Archivo de Cancilleria. Acervo referente ao Cone Sul. Buenos Aires: Archivo de Cancillería, 2018.

MINISTÉRIOS DAS RELAÇÕES EXTERIORES; MINISTÉRIO DE MINAS E ENERGIA; MINISTÉRIO DA INDÚSTRIA E COMÉRCIO. [Ofício] 12 fev.. 1973, Brasília [para] Presidência da República. 1f. Relatório sobre estudos e intercâmbios técnicos com a Bolívia. In: Arquivo Nacional. Acervo referente à ditadura militar brasileira. Brasília: Arquivo Nacional, 2017b, p. 01.

MINISTÉRIO DAS RELAÇÕES EXTERIORES E CULTO DA BOLÍVIA. [Memorando] 25 de setembro 1971, La Paz [para] Ministério de Relações Exteriore do Brasil. Brasília. 02f. Resposta do governo boliviano às requisições brasileiras durante a Primeira Reunião da Comissão Mista Brasileira-boliviana de Cooperação Econômica 
DE SOUZA, Eliton Felipe. A disputa hegemônica brasileira com a república da argentina - o caso da ingerência na Bolívia. Revista Eletrônica Direito e Política, Programa de Pós-Graduação Stricto Sensu em Ciência Jurídica da UNIVALI, Itajaí, v.14, n.1, $1^{0}$ quadrimestre de 2019. Disponível em: www.univali.br/direitoepolitica - ISSN 1980-7791

e Técnica. In: Arquivo Nacional - Ministério da Justiça e Segurança Pública. Acervo da Ditadura Militar. Brasília: Arquivo Nacional, 2017, p. 01.

MORAIS, Lindocastro Nogueira de; LIMA, Jhéssica Luara Alves de. Cooperação internacional em matéria de prova civil. Revista Eletrônica Direito e Política, Itajaí, v.11, n.3, 30 quadrimestre de 2016. Disponível em: www.univali.br/direitoepolitica.

NETO, Sydenham Lourenço. A Conferência do Rio de Janeiro e o Tratado Interamericano de Assistência Recíproca: Conflitos na construção do sistema interamericano. Revista Internacional de História Política e Cultura Jurídica. Rio de Janeiro, vol. 7, n. 3, set/dez, 2015, p. 473-489. Disponível em: <http://www.historia.uff.br/revistapassagens/artigos/v7n3a32015.pdf> Acesso em: 01/01/2018. DOI: 10.15175/1984-2503-20157303.

NOGUEIRA, José Manuel Freire. América do Sul: uma visão geopolítica. Lisboa: Instituto da Defesa Nacional; EUROPRESS, 2015.

PHILIPPI, Patricia Pasqualini; ZICARELLI, Leonardo. O direito transnacional ambiental e a proteção do direito ao desenvolvimento humano. Revista Eletrônica Direito e Política, Itajaí, v.8, n.3, 30 quadrimestre de 2013. Disponível em: www.univali.br/direitoepolitica acessado em 25/04/2019.

PRESIDÊNCIA DA REPÚBLICA - SERVIÇO NACIONAL DE INFORMAÇÃO - AGÊNCIA CENTRAL. [Telegrama] 03 ago. 1970, Brasília [para] [?]. Brasília. 11f. O movimento subversivo na América Latina - Bolívia: alvo prioritário. In: Arquivo Nacional - Ministério da Justiça e Segurança Pública. Acervo da Ditadura Militar. Brasília: Arquivo Nacional, 2017, p. 03.

. [Telegrama] 03 ago. 1970, Brasília [para] [?]. Brasília. 11f. O movimento subversivo na América Latina - Bolívia: alvo prioritário. In: Arquivo Nacional - Ministério da Justiça e Segurança Pública. Acervo da Ditadura Militar. Brasília: Arquivo Nacional, 2017, p. 01-06.

PRESIDÊNCIA DA REPÚBLICA - CONSELHO DE SEGURANÇA NACIONAL SECRETARIA-GERAL. [Ata] 10 de julho de 1968. 79f. Ata da quadragésima primeira sessão do Conselho de Segurança Nacional. In: Documentos Revelados. Acervo referente às Atas do Conselho de Segurança Nacional 1968. Foz do Iguaçú: Arquivo Documentos Revelados, 2018, p. 05.

SECRETARIA DE ESTADO DAS RELAÇÕES EXTERIORES. [Estudo Especial] 14 ago. 1970, Brasília. 9f. Diretrizes de ordem política com relação a um possível agravamento da situação político-militar da Bolívia. In: Arquivo Nacional Ministério da Justiça e Segurança Pública. Acervo da Ditadura Militar. Brasília: Arquivo Nacional, 2017, p. 09. 
DE SOUZA, Eliton Felipe. A disputa hegemônica brasileira com a república da argentina - o caso da ingerência na Bolívia. Revista Eletrônica Direito e Política, Programa de Pós-Graduação Stricto Sensu em Ciência Jurídica da UNIVALI, Itajaí, v.14, n.1, $1^{0}$ quadrimestre de 2019. Disponível em: www.univali.br/direitoepolitica - ISSN 1980-7791

SECRETARIA GERAL DO CONSELHO DE SEGURANÇA NACIONAL. [Memorando] 05 jun. 1973, Laz Paz [para] Secretário Geral do Conselho de Segurança Nacional. Brasília D.F.. 4f. Aspectos políticos-militares da Bolívia.In: Arquivo Nacional Ministério da Justiça e Segurança Pública. Acervo da Ditadura Militar. Brasília: Arquivo Nacional, 2017, p. 01-04.

SERVICIO NACIONAL DE CAMINOS DE BOLÍVIA - DIVISÃO DE PLANEJAMENTO; DIVISÃO DE CONSTRUÇÕES; DIVISÃO DE PONTES. [Relatório] mai. 1972, La Paz. [para] Servicio Nacional de Caminos de Bolívia. La Paz.11f. Informe sobre el seminario de puentes y visita a obras realizado en la Reublica Argentina.. In: Archivo de Cancillería. Acervo referente ao Cone Sul. Buenos Aires: Archivo de Cancillería, 2018.

SIVAK, Martín. El dictador elegido: biografia no autorizada de Hugo Banzer. La Paz: Plural Editores, 2001.

TOLFO, Andreia Cadore. A origem da previsão constitucional da participação do poder legislativo na conclusão dos tratados internacionais. Revista Eletrônica Direito e Política, Itajaí, v.8, n.3, 30 quadrimestre de 2013. Disponível em: www.univali.br/direitoepolitica acessado em: 25/04/2019.

RECEBIDO EM: 15/01/2019

APROVADO EM: 20/03/2019 